First Peoples Child \& Family Review

An Interdisciplinary Journal Honouring the Voices, Perspectives, and Knowledges of First Peoples through Research, Critical Analyses, Stories, Standpoints and Media Reviews

\title{
Jumping through hoops: An overview of the experiences and perspectives of Aboriginal mothers involved with child welfare in Manitoba
}

\section{Marlyn Bennett, Leslie Spillett and Catherine Dunn}

Volume 7, Number 1, 2012

URI: https://id.erudit.org/iderudit/1068866ar

DOI: https://doi.org/10.7202/1068866ar

See table of contents

Publisher(s)

First Nations Child and Family Caring Society of Canada

ISSN

1708-489X (print)

2293-6610 (digital)

Explore this journal

Cite this article

Bennett, M., Spillett, L. \& Dunn, C. (2012). Jumping through hoops: An overview of the experiences and perspectives of Aboriginal mothers involved with child welfare in Manitoba. First Peoples Child \& Family Review, 7(1), 76-83.

https://doi.org/10.7202/1068866ar

\section{Article abstract}

This article provides an overview of the experiences of Aboriginal mothers involved with child welfare in Manitoba. Jumping through hoops was a prominent perspective evident in stories and reflections that Aboriginal mothers shared about their experiences with child welfare and legal systems. The research drew upon interviews and talking circles conducted with Aboriginal women, and included interviews conducted with community advocates and lawyers in the spring and summer of 2007.
This document is protected by copyright law. Use of the services of Erudit (including reproduction) is subject to its terms and conditions, which can be viewed online.

https://apropos.erudit.org/en/users/policy-on-use/ 


\title{
First Peoples Child \& Family Review
}

An Interdisciplinary Journal Honoring the Voices, Perspectives and Knowledges of First Peoples through Research, Critical Analyses, Stories, Standpoints and Media Reviews

\section{Jumping through hoops: An overview of the experiences and perspectives of Aboriginal mothers involved with child welfare in Manitoba}

\author{
Marlyn Bennetta, Leslie Spillett ${ }^{\mathrm{b}}$, and Catherine Dunn ${ }^{\mathrm{c}}$ \\ a Director of Research, First Nations Child \& Family Caring Society of Canada, Winnipeg, MB, Canada \\ ${ }^{\mathrm{b}}$ Executive Director, Ka Ni Kanichink Inc., Winnipeg, MB, Canada \\ ${ }^{b}$ Lawyer, Catherine Dunn Law Office, Winnipeg, MB, Canada
}

\begin{abstract}
This article provides an overview of the experiences of Aboriginal mothers involved with child welfare in Manitoba. Jumping through hoops was a prominent perspective evident in stories and reflections that Aboriginal mothers shared about their experiences with child welfare and legal systems. The research drew upon interviews and talking circles conducted with Aboriginal women, and included interviews conducted with community advocates and lawyers in the spring and summer of 2007.
\end{abstract}

\section{Introduction}

In 2005, Ka Ni Kanichihk, an urban-based Aboriginal organization in Winnipeg, launched a study focusing on the experiences and disproportionate representation of Aboriginal women involved in the child protection system in Manitoba and consequently the role of the justice system in their lives and those of their children. Ka Ni Kanichihk, along with several community organizations and institutions, created a coalition of stakeholders to oversee the project and to explore the nature of Aboriginal mothers' experiences in child protection cases before the courts.

This paper describes the perception Aboriginal mothers have of their experiences with child welfare workers, the child welfare system, and legal representatives, and the understanding Aboriginal mothers have of alternative dispute resolutions. In addition, this paper highlights the solutions and recommendations made by mothers involved in this study to help the child welfare and family court systems improve relations and work with and for Aboriginal mothers and their children.

Corresponding author:

Marlyn Bennett, (204) 452-9467

mbennett@fncaringsociety.com

\section{Methodology}

This research took a phenomenological approach to understanding lived experiences and perceptions about child welfare and legal systems through the personal lens of Aboriginal mothers and grandmothers. 


\section{First Peoples Child \& Family Review, Volume 7, Number 1, 2012}

\section{Sample}

Participants included 32 Aboriginal mothers ${ }^{1}$ who have had, or were at risk of having, their children apprehended by the child welfare system in Manitoba due to child protection concerns. Participants were recruited between March and June 2007 from Winnipeg and The Pas using an email strategy, word of mouth, and formal invitations by the research team through their various network connections. Criteria required that participants be Aboriginal (First Nations, Métis, Inuit, or non-status Aboriginal) women 18 years of age or older. The majority of the women were 41-50 years old single mothers. The sample included women who participated in both a one-onone personal interview and one of three talking circles.

\section{Procedures}

A detailed literature review was conducted to explore the extent and complexity of Aboriginal mothers' experiences with the child welfare and court systems in Canada ${ }^{2}$. A survey was created to collect background/personal information. In-depth, open-ended interviews were conducted with each participant by one of three team members. Two non-traditional talking circles were held in Winnipeg, and one was held in The Pas.

\section{Data Analysis}

All interviews and talking circles were audio-taped and later transcribed verbatim. Each interview was thematically analyzed. The interviews and talking circles conducted for this study yielded over 500 pages of rich narrative text once transcribed.

\section{Results}

The mothers often started out by sharing stories about how they first came into contact with the child welfare system. For many of these mothers, involvement with the child welfare system began when they were children or youth themselves and continued into adulthood when they had children of their own. Their stories reflect collective and common perceptions about how the child welfare system functions and operates against them because of their life circumstances.

Collectively, the mothers' narratives reflected six predominant themes3:

1. How Aboriginal mothers came into contact with child welfare

2. The context of the mothers' lives

3. Specific experiences with the child welfare system (e.g., treatment by child welfare staff and supervisors, racism, visitation, etc.);

4. Insight of mothers into their own experiences (e.g., acknowledging their own mistakes, emotions, coping, etc.)

5. Experiences with lawyers

6. Mothers' knowledge around alternative dispute resolution

The following sections focus on only three of the six themed areas: experiences with child welfare, experiences with lawyers, and mothers' knowledge of alternative dispute resolution mechanisms used in the child welfare context. 


\section{Jumping through hoops: An overview}

\section{Experiences with the Child Welfare System}

\section{Fear of "the system"}

Mothers expressed great fears around seeking out treatment or assistance they needed for fear that their children would be apprehended. This is reflected in the following comment:

I was even scared to go for treatment because I figured ... if I'm gonna go for treatment then it means I got a problem and they're gonna find a reason to take my kids away. And that's what happened, right? I ... tried to do that anyway and then they wound up taking my kids away.

\section{Being monitored}

A few of the narratives spoke of being subjected to numerous drug and alcohol tests by child welfare agency staff. Closely related to drug and alcohol testing was the feeling of being watched by child welfare. Mothers felt strongly that being under scrutiny was an invasion of their privacy. This is evident in the comment by this mother:

... they would get somebody to spy on my home, they knew people were coming in there, they had specific names. They had people watching my home and I'm going to try to make a court case saying that's invasion of my privacy and movement.

\section{Triggering mothers' anger}

Mothers often felt that social workers deliberately tried to make them angry, as this mother reflected:

They want to set you up. There are key words and there are key things they try to throw at you to make you fly off the handle. I'm not stupid; I know their game.

\section{Visitation arrangements}

Mothers who participated in the interviews and talking circles unanimously admitted to experiencing many problems and difficulties around their visitation rights. Visits were inconsistent, held infrequently, and were often too short. Mothers stated that visits were often supervised and took place in the office of the child welfare agency:

I looked forward to the Saturday visitations I had with them for an hour. That was very hard, very hard to see them crying because they had to leave me. And it's not like I could walk to a park and be alone with them; I had to be supervised. I'm not an abusive mom ... that I could not understand. What did they think I was going to do with my kids? It was awful.

\section{Harm to children while in care.}

In addition to the pain and loss experienced by Aboriginal mothers when their children were removed from them, many mothers expressed fear and concern over the impact on their children of removal. The most frequently cited worry that mothers brought to our attention was that their children would have been or actually were sexually abused while in care: 
First Peoples Child \& Family Review, Volume 7, Number 1, 2012

At one point my family had to intervene because my kids were in a foster home where it was a cult. There was sexual abuse going on. There was physical abuse going on. The foster mom actually got her licensed pulled.

Mothers also viewed the loss of opportunities to develop deeper relationships with their children as a profound impact of the removal.

\section{Child welfare expectations and programming}

Many of the mothers shared that they attended numerous programs at the request of the child welfare worker and agency. For many of the mothers, it felt as though they were over-programmed and expectations seemed to change from month to month:

I had to jump through hoops ... going through parenting programs ... I don't even know how many programs ... I went for treatment. ... I got so many certificates it's unreal.

\section{Jumping through hoops}

Mothers reported feeling that they had to jump through hoops to satisfy child welfare workers. This sentiment was reflected in the following comments:

You're a person who's trying to live your life and then you're going to try and jump through

hoops ... this jumping through hoops business was getting me mad.

It's just one frustration after another. It's like you have to jump through hoops ... they don't tell you exactly what it is that they want.

\section{Experiences with lawyers}

The issue of rights and lack of knowledge around their rights as parents was a predominant theme in conversations with mothers. Mothers also shared both positive and negative experiences dealing with lawyers representing them in child protection cases. Mothers' discussions touched upon the court experience and their knowledge, or lack of knowledge, about alternative resolutions to child welfare matters.

\section{Lack of awareness regarding rights}

Mothers stated that, when Child and Family Services first apprehended their children, they often did not know where to turn for help and assistance. They were not sure how to obtain a lawyer or where to get Legal Aid assistance. They felt that the child welfare workers they came into contact with were not helpful in providing the information mothers needed to understand what to do next.

Aboriginal mothers made numerous comments about the quality of services provided by the Legal Aid lawyers who represented them in child protection matters before the courts. Evaluation of the quality of legal services received was primarily negative. Many mothers indicated that their lawyers did not appear to adequately defend or represent them in court. Many said their lawyers counseled them to agree with the decisions made by the child welfare agency. For many, it appeared that the lawyers worked for child welfare agencies and made decisions in consultation 


\section{Jumping through hoops: An overview}

with child welfare agencies rather than with the mothers they represented. This perception is evident in the adamant statement from this mother:

I don't know who told me ... they said [the lawyer] works for Child and Family Services.... Wouldn't that be a conflict of interest for her to take my case against them because she works for them? All she was trying to do was make me sign papers to do whatever they wanted. I knew deep down inside, no I'm not doing it. I don't feel right about it.

In many instances, mothers indicated that they had a minimal amount of time with their lawyers prior to the courtroom experiences and felt their lawyers were essentially strangers who did not provide them with the sort of strength, comfort, and friendship they needed under the circumstances.

The majority of mothers interviewed for this study agreed that family law courts are not an appropriate environment to oversee child protection issues involving Aboriginal families. The common response from mothers in this study was that courts are a very intimidating setting where many felt harshly judged. The mothers' sense of intimidation was connected to difficulties understanding the terminology and language used within the courtroom. Their collective perception centers around the belief that, within the court setting, the decisions made by judges are one sided, and favour the interpretation of the child welfare agencies.

\section{Lack of courtroom supports and advocates}

Mothers expressed concerns about not being allowed to bring supportive people with them into the courtroom to face judges, lawyers, child welfare staff, and other courtroom personnel. The inequity of the situation was reflected by one mother this way:

The advocate ... wasn't allowed in the courtroom. Well ... what I said was, "Oh, you guys are allowed all your people but I'm not allowed to have mine?”... No, you need someone there! They need to change that definitely. You should be allowed whoever you want in court with you....

\section{Knowledge of alternative dispute resolutions used in the child welfare context}

None of the mothers interviewed for this study were aware of the various alternative dispute resolutions that could be used in the child welfare context (e.g., mediation or family group conferencing). Mothers admitted they were not knowledgeable about any mediation approaches that might have helped them deal with the negativity they encountered when interacting with child welfare staff. Furthermore, Aboriginal mothers reported that child welfare staff and lawyers rarely offered suggestions to alleviate the tension inherent throughout the child welfare experience. There really was no alternative, as this mother noted:

I don't know any alternatives other than going to court and trying to fight and saying, 'No, I want my kid back', and that's the only thing I know... I don't know ... what there is ... for someone in my situation ... The only way is their way and ... they're the law. They're the justice system.

\section{Optimism for the future}

Regardless of the time children spend in care, mothers in this study were optimistic that they would resume a relationship with their children once they transitioned out of the child welfare system. Despite their circumstances, the mothers indicated that they continued to work on 


\section{First Peoples Child \& Family Review, Volume 7, Number 1, 2012}

themselves in order to be strong for the day when they might be reunited with their children, as this mother poignantly shared:

It hurts, but I know one day my children are going to be 18 , and if they turn 18 and they decide to come home, I want to be mentally and physically ready for my children. And I want to be healthy for my children. So I know I have a lot of healing and work to do on myself.

\section{Mothers' recommendations for change}

This study gave Aboriginal mothers an opportunity to voice their perspectives about their experiences and to provide suggestions for simple changes that might help mothers better understand the child welfare system. The following recommendations were generated from a synthesis of the responses provided by the mothers and by the researcher's observations and analyses of the findings.

1. Development of an Aboriginal Mothers' Advocates Office or Institute. This would provide a formal organization to help Aboriginal mothers navigate all aspects of the child welfare system within the Province of Manitoba.

2. Establishment of a training program for Aboriginal Mothers' Advocates. The Aboriginal Mothers' Advocates Office would be responsible for training Aboriginal mothers to become advocates. The mothers in this study suggested that advocates be mothers who have intimate knowledge and experience dealing with the child welfare and legal systems.

3. Development of a manual on the child welfare and legal systems. This manual would outline the things Aboriginal mothers could expect during their contact with child welfare/ court processes. It should include the following:

- Anticipated timelines

- User-friendly terms and definitions

- Information on the legal process

- Information on how to access and instruct legal counsel

- Information on access to programs and treatment resources for Aboriginal mothers involved with the child welfare system

4. Development of mothers' support groups. The mothers in this study identified the need to develop more support groups across the province for Aboriginal mothers involved with the child welfare system.

5. Courtroom Advocates. Mothers in this study suggested that close family, friends, and other supporters should be allowed into courtrooms.

6. Development of a website. A website could include the following:

- Information about the Aboriginal Mothers' Advocates Office

- Listing of courtroom advocates

- Listing of training opportunities

- A calendar of support group activities

- A listing of the resources, programs, and treatment options available to Aboriginal mothers involved with child welfare 


\section{Jumping through hoops: An overview}

- Listing of and link to contact information for lawyers who specialize in child welfare matters.

7. Development of an anthology of Aboriginal mothers/grandmothers' stories and experiences. There are very few resources that celebrate what it means to be an Aboriginal mother and grandmother. This recommendation would see the creation of a book that gives Aboriginal mothers and grandmothers a chance to share stories that reflect the challenges faced by Aboriginal mothers and celebrates their strength and resilience.

\section{Discussion and Conclusion}

There is a clear need to move the child welfare and legal systems toward the use of alternative strategies when working with Aboriginal families. Fundamental changes to the child welfare system can only happen when room is made for collaborative dialogue between those with power to change system structures and those with courage to challenge existing oppression. The recommendations arising from this research seem to advocate "tinkering" with the current system rather than making fundamental changes. This may reflect a general lack of knowledge on the part of Aboriginal mothers (and many service personnel working in the child welfare system) about available alternative dispute resolution mechanisms. It may also be due to the fact that Aboriginal women lack the power to ensure profound changes to these systems. The economic and logistic feasibility of moving any recommendations forward have yet to be explored. However, Aboriginal mothers and Elders should be involved at every stage in exploring, developing, and implementing proposed solutions.

It is important to note limitations of this work, including the subjective nature of the data produced, limited generalizability of the findings common within qualitative study designs, and a lack of interviews with service providers, which were originally targeted in the work plan.

The voices of mothers and their experiences within the child welfare system have been missing from child welfare literature for far too long. Preliminary findings from this study contribute to evidentiary research that can help child welfare administrators, policy makers, front line staff, and funders assess and tailor services that will engage Aboriginal mothers, children, and families in a more participatory manner that ensures cultural appropriateness and respect for the sacredness of Aboriginal motherhood. The responsibilities of child welfare must be shared, and it is hoped that governments will recognize that Aboriginal children will be healthier and safer only when Aboriginal mothers, fathers, families, and communities are given adequate resources.

\section{Endnotes}

1. Many of the women who participated in this study also identified themselves as grandmothers. This paper reflects the voices and perspectives of both mothers and grandmothers, collectively referred to here as "mothers."

2. An extensive literature review was produced in the summer of 2006. See Bennett, M. (2006). Aboriginal mothers' involvement with child protection and family court systems: Examining alternative court processes. Canada's Children, 13(1), 88-93. Available from http://www.cwlc.ca/en/publications/canadas-children. 
First Peoples Child \& Family Review, Volume 7, Number 1, 2012

3. The full report, which captures the essence of these findings, can be downloaded from the Caring Society website at http://www.fncaringsociety.com/sites/default/files/docs/Final_ Report_FCDP_Bennett_2008_print.pdf. 